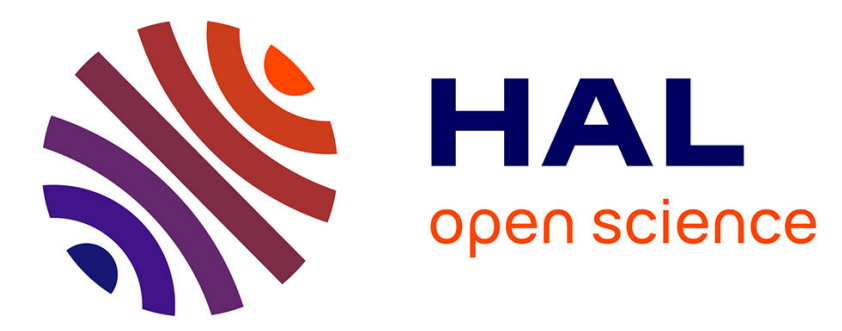

\title{
Synthesis, characterization, X-ray structure and in vitro antifungal activity of triphenyltin complexes based on pyrazole dicarboxylic acid derivatives
}

Mohammed Dahmani, Abdelkader Et-Touhami, Abderrahmane Yahyi, Tarik Harit, Driss Eddike, Monique Tillard, Redouane Benabbes

\section{To cite this version:}

Mohammed Dahmani, Abdelkader Et-Touhami, Abderrahmane Yahyi, Tarik Harit, Driss Eddike, et al.. Synthesis, characterization, X-ray structure and in vitro antifungal activity of triphenyltin complexes based on pyrazole dicarboxylic acid derivatives. Journal of Molecular Structure, 2021, 1225, pp.129137. 10.1016/j.molstruc.2020.129137 . hal-02927096

\section{HAL Id: hal-02927096 \\ https://hal.science/hal-02927096}

Submitted on 23 Nov 2020

HAL is a multi-disciplinary open access archive for the deposit and dissemination of scientific research documents, whether they are published or not. The documents may come from teaching and research institutions in France or abroad, or from public or private research centers.
L'archive ouverte pluridisciplinaire HAL, est destinée au dépôt et à la diffusion de documents scientifiques de niveau recherche, publiés ou non, émanant des établissements d'enseignement et de recherche français ou étrangers, des laboratoires publics ou privés. 


\section{Synthesis, Characterization, X-Ray Structure and in Vitro Antifungal Activity of Triphenyltin complexes based on Pyrazole Dicarboxylic Acid Derivatives.}

Mohammed Dahmani ${ }^{\mathrm{a}}$, Abdelkader ET-TOUHAMI ${ }^{\mathrm{a},}{ }^{*}$, Abderrahmane YAHYI ${ }^{\mathrm{a}}$, Tarik HARIT $^{a}$, Driss EDDIKE ${ }^{b}$, Monique TILLARD ${ }^{\mathrm{c}}$ and Redouane BENABBES ${ }^{\mathrm{d}}$

\footnotetext{
${ }^{a}$ Laboratory of Applied Chemistry and Environment-ECOMP, Faculty of Sciences, Mohammed First University Bd Mohamed VI, BP: 717, Oujda 60000, Morocco.

${ }^{b}$ Laboratory of Applied Chemistry and Environment-CSM, Faculty of Sciences, Mohamed First University, Bd Mohamed VI, BP 717, Oujda 60000, Morocco. ${ }^{\circ} I C G M$, CNRS, Université de Montpellier, ENSCM, Montpellier, France.

${ }^{d}$ Laboratory of Biochemistry, Faculty of Sciences, Mohammed First University, 60000 Oujda, Morocco.
}

*Corresponding author: Tel.: +212 536 500601, Fax: +212 536 500603, E-mail Address: touhami_52@yahoo.fr (Abdelkader ET-TOUHAMI) 


\begin{abstract}
A series of new ditriphenyltin(IV) dicarboxylate complexes of general formula $\left(\mathrm{Ph}_{3} \mathrm{SnOOC}\right.$ $\mathrm{Pz})_{2} \mathrm{R}$ with Pz: pyrazole and R: alkyl or ether, have been synthesized from bipyrazoledicarboxylic acid and hydroxytripheyltin. These complexes, noted C1-C7, have been characterized by IR, ${ }^{1} \mathrm{H}$ and ${ }^{13} \mathrm{C}$ NMR spectroscopies. The molecular structures of C3: 1,3Bis[(5-methyl-2-H-3-triphenyltincarboxylate pyrazol)]propane and C7: Bis[(2-methyl-2H-3triphenyltincarboxylate pyrazol)ethyl]oxide have been confirmed by single crystal X-ray diffraction. Both compounds crystallize in the monoclinic symmetry: $\mathbf{C} 3$ in $\mathrm{P} 2{ }_{1}$ space group with $\mathrm{a}=15.915(1) \AA, \mathrm{b}=10.0791(8) \AA, \mathrm{c}=13.823(1) \AA, \alpha=90^{\circ}, \beta=100.459(3)^{\circ}, \gamma=90^{\circ}$ and C7 in $\mathrm{P} 21 / \mathrm{n}$ space group, with $\mathrm{a}=15.0951(7) \AA, \mathrm{b}=8.9847(3) \AA, \mathrm{c}=34.244(1) \AA, \alpha=90^{\circ}, \beta$ $=101.421(2)^{\circ}, \gamma=90^{\circ} .$. The two cristallographically independent $\mathrm{Sn} 1$ and $\mathrm{Sn} 2$ atoms are tetra coordinated within distorted tetrahedral environments, very similar in the two compounds. The antifungal activity of these organotin complexes and their corresponding bipyrazoledicarboxylic acid (ligands) has been evaluated against the pathogenic Fusarium oxysporum f. sp. albedinis. This activity greatly depends on the nature of ligands and on the dose used. The presence of triphenyltin moiety improves considerably the antifungal activity becoming close to that of the benomyl (fungicide).
\end{abstract}

Keywords: Antifungal Activity; Bipyrazoledicarboxylic Acid; Crystal Structure; Fusarium oxysporum f. sp. albedinis; Triphenyltin; Spectroscopy. 


\section{Introduction}

Organometallic derivatives, in particular organotin (IV) carboxylates, have attracted much attention in the past two decades for their potential biological activities [1-3] and their structural diversity, in particular triorganotin (IV) carboxylates which present a rich and diverse structural chemistry, as reported in the literature [1-3].

Due to their interesting cytotoxic activities, several triorganotin carboxylates have been prepared and tested in recent years as antitumor [1-3] antiviral [4-5], antibacterial [6-7], antifungal [8-9], antimicrobial, anti-proliferative [10-11], anti-inflammatory [12], antioxidant [13]. In the agricultural environment, Fusarium oxysporum is one of the most important fungal organisms present in the cultivated soils. It alone constitutes 40 to $70 \%$ of the total Fusarian flora. It is represented by a set of very variable forms both from the morphological and physiological point of view. The number of Fusarium oxysporum forms is estimated at 100 . Among them are those capable of causing disease in plants, such as the Fusarium oxysporum $\mathrm{f}$. sp. lycopersici which attacks tomatoes and celery. Fusarium oxysporum f. sp. albedinis, causative agent of the vascular fusarium wilt of the date palm (Bayoud) and Fusarium oxysporum f. sp. cubense, causative agent of fusarium wilt of banana, are also responsible for the two most serious diseases [14].

The systematic study of the antifungal activity of organotin compounds was actually launched in 1950 by van Derk and Luijten [15]. They evidenced the high fungitoxicity of compounds of the type $\mathrm{R}_{3} \mathrm{SnX}$. The Tr-n-propyl and tr-n-butyltin acetates inhibit the growth of test fungi at low concentrations [16-17]. Tri-m-tolyl-and tri-p-tolyltin acetates differ little from triphenyltin acetate and have nearly the same activity as triethyltin acetate [16-17]. Triphenyltin acetate, the first agricultural organotin fungicide, was developed by K. Hartel in 1962 [18]. In 1992, Gielen and al. [19] published results of antifungal tests for a series of organotin compounds of salicylic acid derivatives against different fungal strains as Fusarium nivale, Fusarium avenaceum and 
Phytophtora, and triphenyltin-5-methoxysalicylate is the most active compound. Yahyi and al. [20] studied in 2007 the effects on antifungal activity of certain triphenyltins of pyrazolic carboxylic acid. All the derivatives show markedly high antifungal in vitro activity against the growth of the Fusarium.

On the other hand, the bipyrazole derivatives form an interesting class of compounds with potent widespread biological activities. Furthermore, bipyrazolic compounds functionalized with two carboxylic groups (Fig.1) have attracted more attention due to their complexing properties toward metal cations [21-23]. In 2008, Chandrasekhar et al. reported the synthesis and structure of the first dinuclear triorganotin (IV) $\left[\left(\mathrm{Ph}_{3} \mathrm{Sn}\right)_{2}(\mu-\mathrm{LH})\left(\mathrm{H}_{2} \mathrm{O}\right)\right]$ based on bi(pyrazole), obtained from the reaction of $\left(\mathrm{Ph}_{3} \mathrm{Sn}\right)_{2} \mathrm{O}$ with 3,5-pyrazoledicarboxylic acid (LH) [24]. However, no study of their biological activity, whether antitumor or antifungal, has been described. In this context, it was interesting to synthesize new bis(triphenyltin) complexes based on the new pyrazoledicarboxylic acids (Fig.1), to establish their structure and to evaluate their antifungal activity.

The present paper reports the synthesis and spectroscopic characterizations of seven new bipyrazole based triorganotin dicarboxylate complexes, which differ by the nature and the length of spacers between the two pyrazol rings. The results of their antifungal potency examined against Fusariumoxysporum f. sp.albedinis are also provided.

\section{Experimental}

3.

\subsection{Characterization}

All reagents and solvents were purchased from Sigma-Aldrich and used as received. BRÜKER AC 300 was used to record the NMR spectra. Spin resonances are given as 
chemical shifts ( $\delta$ ) in parts per million (ppm) and referenced to the residual peak as an internal standard of the solvent employed, as follow: $\mathrm{CDCl}_{3} 7.27 \mathrm{ppm}$ and DMSO- $\mathrm{d}_{6} 2.50 \mathrm{ppm}$ for ${ }^{1} \mathrm{H}$ NMR, and 77 ppm 39.5 ppm for ${ }^{13} \mathrm{C}$ NMR. Spin multiplicity is presented by $\mathrm{s}=$ singlet, $\mathrm{d}=$ doublet, $\mathrm{t}=$ triplet, $\mathrm{q}=$ quartet, $\mathrm{m}=$ multiplet. Melting point uncorrected was recorded in capillary on IA9100 (Electrothermal) apparatus. FTIR spectra were realized on Shimadzu FTIR 8400s spectrophotometer. UV-Vis spectra were recorded on Shimadzu Europe - UV1650PC.

\subsection{Synthesis}

\subsubsection{Synthesis of compounds $1-7$}

Compounds1,1-Bis(3'-ethoxycarbonyl-5'-methyl-l'H-pyrazolyl) methane $\quad$ 1; $\quad 1,2-$ Bis(3'ethoxycarbonyl-5'-methyl-1'H-pyrazolyl) ethane 2; 1,3-Bis(3'-ethoxycarbonyl-5'methyl-1'Hpyrazolyl)propane 3; 1,3-Bis(3'-ethoxycarbonyl-5'-methyl-l'H-pyrazolyl)butane 4; 1,6Bis(3'-ethoxycarbonyl-5'-methyl-1'H-pyrazolyl) hexane 6 and Bis (2-(3'-ethoxycarbonyl5'methyl-1'H- pyrazol) ethyl) oxide 7 were synthesized according to the procedure reported in our previous work [23, 25-28]. Characteristics for compound 1,5-Bis(3'-ethoxycarbonyl5'methyl-l'H-pyrazolyl)pentane 5, also prepared in this way (yield $=78 \%$ ): $\mathrm{mp}=83{ }^{\circ} \mathrm{C} .{ }^{1} \mathrm{H}$ $\operatorname{NMR}\left(300 \mathrm{MHz}, \mathrm{CDCl}_{3}\right) \delta: 1.25\left(\mathrm{t}, 6 \mathrm{H}, \mathrm{O}-\mathrm{CH}_{2}-\mathrm{CH}_{3}\right) ; 1.27\left(\mathrm{~m}, 2 \mathrm{H},-\mathrm{C}_{2}-\mathrm{CH}_{2}-\mathrm{CH}_{2}\right) ; 1.70$ (m, $\left.4 \mathrm{H},-\mathrm{CH}_{2}-\underline{\mathrm{C}}_{2}-\mathrm{CH}_{2}\right) ; 2.24$ (s, 6H, $\left.\underline{\mathrm{H}}_{3}-\mathrm{Pz}\right) ; 4.08$ (q, 4H, $\left.\mathrm{CH}_{3}-\underline{\mathrm{C}}_{2}-\mathrm{O}\right) ; 4.23$ (t, 4H, $\underline{\mathrm{C}}_{2}-$ $\mathrm{N}) ; 6.48(\mathrm{~s}, 2 \mathrm{H}, \underline{\mathrm{H}}-\mathrm{Pz}),{ }^{13} \mathrm{C} \mathrm{NMR}\left(75 \mathrm{MHz}, \mathrm{DMSO}-\mathrm{d}_{6}\right) \delta(\mathrm{ppm}): 10.93\left(\underline{\mathrm{C}} \mathrm{H}_{\underline{3}}-\mathrm{Pz}\right) ; 14.65$ $\left(\underline{\mathrm{CH}_{3}}-\mathrm{CH}_{2}-\mathrm{O}\right) ; 26.82\left(-\underline{\mathrm{CH}}_{\underline{2}}-\mathrm{CH}_{2}-\right) ; 30.01 \quad\left(\mathrm{C}_{2}-\mathrm{CH}_{2}-\mathrm{N}\right) ; 48.92\left(\underline{\mathrm{CH}} \underline{2}_{2}-\mathrm{N}\right) ; 60.82\left(\underline{\mathrm{CH}}_{2}-\right.$ $\mathrm{O}) ; 108.26(\underline{\mathrm{CH}}-\mathrm{Pz}) ; 140.37\left(\mathrm{CH}_{3}-\underline{\mathrm{C}}=\mathrm{C}\right) ; 142.42(\underline{\mathrm{C}}-\mathrm{C}=\mathrm{O}) ; 162.72(\underline{\mathrm{C}}=\mathrm{O}), \mathrm{IR}\left(\mathrm{cm}^{-1}\right): v(\mathrm{C}=\mathrm{O})$ $=1725, \mathrm{v}(\mathrm{C}-\mathrm{O})=1150$. 


\subsubsection{Synthesis of ligands L1-L7}

Ligands 1,1'-(methane-1,2-diyl)bis(5-methyl-1H-pyrazole-3-carboxylic acid L1; 1,1'(ethane1,2-diyl)bis(5-methyl-1H-pyrazole-3-carboxylic acid L2; 1,1'-(propane-1,3-diyl)bis(5methyl1H-pyrazole-3-carboxylic acid L3; 1,1'-(butane-1,4-diyl)bis(5-methyl-1H-pyrazole3carboxylic acid L4; 1,1'-(hexane-1,6-diyl)bis(5-methyl-1H-pyrazole-3-carboxylic acid L6 and 1,1'-(oxybis(ethane-2,1-diyl))bis(5-methyl-1H-pyrazole-3-carboxylic acid L7 were synthesized according to the procedure reported in our previous work [22-23,27]. Characteristics for compound 1,1'-(pentane-1,5-diyl)bis(5-methyl-1H-pyrazole-3-carboxylic acid $\mathbf{L 5}$ also prepared in this way (Yield $=85 \%) .{ }^{1} \mathrm{H}$ NMR $\left(300 \mathrm{MHz}, \mathrm{DMSO}-\mathrm{d}_{6}\right) \delta: 1.22(\mathrm{~m}$, $\left.2 \mathrm{H}, \mathrm{C}_{2}-\left(\mathrm{CH}_{2}\right)_{2}-\mathrm{N}\right) ; 1.69\left(\mathrm{~m}, 4 \mathrm{H}, \mathrm{C}_{2}-\mathrm{CH}_{2}-\mathrm{N}\right) ; 2.24$ (s, 6H, $\left.\mathrm{CH}_{3}-\mathrm{Pz}\right) ; 4.01$ (t, 4H, CH $\left.\mathrm{CH}_{2}-\mathrm{N}\right)$; $6.41(\mathrm{~s}, 2 \mathrm{H}, \mathrm{CH}-\mathrm{Pz}) ; 12.44(\mathrm{~s}, 2 \mathrm{H}, \mathrm{OH}),{ }^{13} \mathrm{C} \mathrm{NMR}\left(75 \mathrm{MHz}, \mathrm{DMSO}-\mathrm{d}_{6}\right) \delta: 10.85\left(\mathrm{CH}_{3}-\mathrm{Pz}\right) ;$ $22.74\left(-\underline{C H}_{2}-\mathrm{CH}_{2}-\mathrm{CH}_{2}-\mathrm{N}\right) ; 31.89\left(-\underline{\mathrm{CH}}_{2}-\mathrm{CH}_{2}-\mathrm{N}\right) ; 48.08\left(-\underline{\mathrm{C}} \mathrm{H}_{2}-\mathrm{N}\right) ; 108.07(\underline{\mathrm{CH}}-\mathrm{Pz}) ; 142.32$ $\left(\mathrm{CH}_{3}-\underline{\mathrm{C}}=\mathrm{C}\right) ; 142.47(\underline{\mathrm{C}}-\mathrm{C}=\mathrm{O}) ; 163.76(\mathrm{COO}) . \operatorname{IR}\left(\mathrm{cm}^{-1}\right): v(\mathrm{OH})=3185 ; v(\mathrm{C}=\mathrm{O})=1690$.

\subsubsection{Synthesis of organotin (IV) carboxylates C1-C7}

-Synthesis of C1: 1, 1-Bis(5-methyl-2-H-3-triphenyltincarboxylate pyrazol) methane A mixture of triphenyltin hydroxide $(0.367 \mathrm{~g}, 1 \mathrm{mmol})$ and $\mathbf{L 1}(0.132 \mathrm{~g}, 0.5 \mathrm{mmol})$ was heated under reflux in toluene $(50 \mathrm{~mL})$ for $10 \mathrm{~h}$ in a Dean-Stark apparatus for azeotropic removal of the water formed in the reaction. After cooling to room temperature, the solution was filtered. Suitable colorless crystals were obtained by a slow evaporation of solvent (Yield $=67 \%)$ : $\mathrm{mp}$ $=104-105^{\circ} \mathrm{C} ;{ }^{1} \mathrm{H}$ NMR $\left(300 \mathrm{MHz}, \mathrm{DMSO}-\mathrm{d}_{6}\right) \delta: 2.24\left(\mathrm{~s}, 6 \mathrm{H}, \underline{\mathrm{C}}_{3}-\mathrm{Pz}\right) ; 6.26\left(\mathrm{~s}, 2 \mathrm{H},-\underline{\mathrm{C}}_{2} \mathrm{~N}\right)$; 6.26 (s, 2H, $\underline{\mathrm{H}}-\mathrm{Pz}) ; 7.63-7.81(\mathrm{~m}, 30 \mathrm{H}, \mathrm{SnPh}),{ }^{13} \mathrm{C} \mathrm{NMR}\left(\mathrm{DMSO}-\mathrm{d}_{6}\right) \delta: 11.30\left(\underline{\mathrm{CH}_{3}}-\mathrm{Pz}\right) ; 67.22$ $\left(-\underline{\mathrm{CH}}_{2}-\mathrm{N}\right) ; 108.53(\underline{\mathrm{CH}}-\mathrm{Pz}) ; 143.53\left(\mathrm{CH}_{3}-\underline{\mathrm{C}}=\mathrm{C}\right) ; 147.11(\underline{\mathrm{C}}-\mathrm{C}=\mathrm{O}) ; 162.60(\mathrm{C}=\mathrm{O}) ;$ Snphenyl skeleton: $138.28\left(\mathrm{C}_{\mathrm{ipso}}\right)$; $137.06\left(\mathrm{C}_{\text {ortho}}\right) ; 128.86\left(\mathrm{C}_{\text {meta }}\right) ; 130.13\left(\mathrm{C}_{\text {para }}\right) . \mathrm{IR}\left(\mathrm{cm}^{-1}\right)$ : 1630 $v_{\text {as }}(\mathrm{COO}) ; 1420 v_{\mathrm{s}}(\mathrm{COO}) ; 560 v(\mathrm{Sn}-\mathrm{C}) ; 465 \mathrm{v}(\mathrm{Sn}-\mathrm{O})$.

-Synthesis of C2: 1,2-Bis(5-methyl-2-H-3-triphenyltincarboxylate pyrazol) ethane 
The complex $\mathbf{C 2}$ was synthesized in a similar way to that of $\mathbf{C 1}$. Suitable yellow crystals were obtained by a slow evaporation of solvent. (Yield $=62 \%): \mathrm{mp}=97-98^{\circ} \mathrm{C} ;{ }^{1} \mathrm{H} \mathrm{NMR}(300 \mathrm{MHz}$,

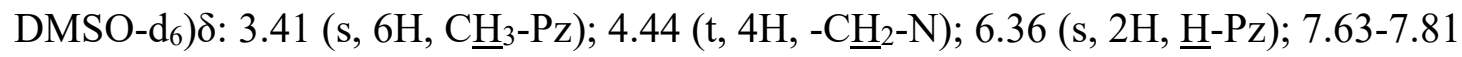
(m, 30H, SnPh), ${ }^{13} \mathrm{C}$ NMR (DMSO-d $)$ ): $10.08\left(\underline{\mathrm{CH}}_{3}-\mathrm{Pz}\right) ; 58.57\left(-\underline{\mathrm{CH}_{2}-\mathrm{N}}\right) ; 108.36(\underline{\mathrm{CH}}-\mathrm{Pz})$ $141.34\left(\mathrm{CH}_{3}-\underline{\mathrm{C}}=\mathrm{C}\right) ; 143.65(\underline{\mathrm{C}}-\mathrm{C}=\mathrm{O}) ; 168.37(\mathrm{C}=\mathrm{O})$; Sn-phenyl skeleton: $138.28\left(\mathrm{C}_{\mathrm{ipso}}\right)$; $137.06\left(\mathrm{C}_{\text {ortho }}\right) ; 128.86\left(\mathrm{C}_{\text {meta }}\right) ; 130.13\left(\mathrm{C}_{\text {para }}\right) . \operatorname{IR}\left(\mathrm{cm}^{-1}\right): 1630 v_{\text {as }}(\mathrm{COO}) ; 1420 v_{\mathrm{s}}(\mathrm{COO}) ; 560$ $v(\mathrm{Sn}-\mathrm{C}) ; 465 v(\mathrm{Sn}-\mathrm{O})$.

-Synthesis of C3: 1,3-Bis(5-methyl-2-H-3-triphenyltincarboxylate pyrazol) propane The complex $\mathbf{C 3}$ was synthesized in a similar way to that of $\mathbf{C 1}$. Suitable yellow crystals were obtained by a slow evaporation of solvent. (Yield $=68 \%): \mathrm{mp}=199-200^{\circ} \mathrm{C} ;{ }^{1} \mathrm{H}$ NMR $(300$ MHz, DMSO-d 6 ) $\delta: 2.13\left(\mathrm{~m}, 2 \mathrm{H},-\underline{\mathrm{CH}}_{2}-\mathrm{CH}_{2}-\mathrm{N}\right) ; 2.24\left(\mathrm{~s}, 6 \mathrm{H}, \underline{\mathrm{C}}_{3}-\mathrm{Pz}\right) ; 3.88\left(\mathrm{t}, 4 \mathrm{H},-\underline{\mathrm{H}}_{2}-\mathrm{N}\right)$; 6.65 (s, 2H, $\underline{\mathrm{HPz}}) ; 7.63-7.81(\mathrm{~m}, 30 \mathrm{H}, \mathrm{SnPh}) .{ }^{13} \mathrm{C}$ NMR $\left(75 \mathrm{MHz}, \mathrm{DMSO}-\mathrm{d}_{6}\right) \delta: 10.83\left(\underline{\mathrm{CH}}_{3^{-}}\right.$ Pz); $58.5\left(-\underline{\mathrm{CH}}_{2}-\mathrm{N}\right) ; 29.5\left(\underline{\mathrm{CH}}_{2}-\mathrm{CH}_{2}-\mathrm{N}\right) ; 108.45(\underline{\mathrm{CH}}-\mathrm{Pz}) ; 142.20\left(\mathrm{CH}_{3}-\underline{\mathrm{C}}=\mathrm{C}\right) ; 143.69(\underline{\mathrm{CC}}=\mathrm{O}) ;$ $166.08(\mathrm{C}=\mathrm{O})$, Sn-phenyl skeleton: $128.86\left(\mathrm{C}_{\text {meta }}\right) ; 136.98\left(\mathrm{C}_{\mathrm{ipso}}\right) ; 136.75\left(\mathrm{C}_{\text {ortho }}\right)$; $130.3\left(\mathrm{C}_{\mathrm{para}}\right) . \mathrm{IR}\left(\mathrm{cm}^{-1}\right): 1650 v_{\mathrm{as}}(\mathrm{COO}) ; 1400 v_{\mathrm{s}}(\mathrm{COO}) ; 530 v(\mathrm{Sn}-\mathrm{C}) ; 460 v(\mathrm{Sn}-\mathrm{O})$.

- Synthesis of C4: 1,4-Bis(5-methyl-2-H-3-triphenyltincarboxylate pyrazol) butane The complex $\mathbf{C 4}$ was synthesized in a similar way to that of $\mathbf{C 1}$. Suitable yellow crystals were obtained by a slow evaporation of solvent.(Yield $=62 \%): m p=179-180^{\circ} \mathrm{C} ;{ }^{1} \mathrm{H}$ NMR $(300$ MHz, DMSO-d 6$) \delta: 1.62\left(\mathrm{~m}, 4 \mathrm{H},-\underline{\mathrm{C}}_{2}-\mathrm{CH}_{2}-\mathrm{N}\right) ; 2.16\left(\mathrm{~s}, 6 \mathrm{H}, \underline{\mathrm{C}}_{3}-\mathrm{Pz}\right) ; 3.90\left(\mathrm{t}, 4 \mathrm{H},-\underline{\mathrm{H}}_{2}-\mathrm{N}\right)$; 6,26 (s, 2H, $\underline{\mathrm{HPz}}) ; 7.63-7.81(\mathrm{~m}, 30 \mathrm{H}, \mathrm{SnPh}) .{ }^{13} \mathrm{C} \mathrm{NMR}\left(75 \mathrm{MHz}, \mathrm{DMSO}-\mathrm{d}_{6}\right) \delta: 11.08\left(\underline{\mathrm{CH}_{3}-}\right.$ Pz); $26.5\left(\underline{\mathrm{CH}_{2}}-\mathrm{CH}_{2}-\mathrm{N}\right) ; 86.18\left(-\underline{\mathrm{CH}}_{2}-\mathrm{N}\right) ; 105,90(\underline{\mathrm{C}} \mathrm{H}-\mathrm{Pz}) ; 136.46\left(\mathrm{CH}_{3}-\underline{\mathrm{C}}=\mathrm{C}\right) ; 142.28(\underline{\mathrm{CC}}=\mathrm{O})$; $174.53(\mathrm{C}=\mathrm{O})$, Sn-phenyl skeleton: $128.86\left(\mathrm{C}_{\text {meta }}\right) ; 136.98\left(\mathrm{C}_{\mathrm{ipso}}\right) ; 136.75\left(\mathrm{C}_{\text {ortho }}\right) ; 130.3$ $\left(\mathrm{C}_{\text {para }}\right) . \operatorname{IR}\left(\mathrm{cm}^{-1}\right): 1650 v_{\text {as }}(\mathrm{COO}) ; 1400 v_{\mathrm{s}}(\mathrm{COO}) ; 530 v(\mathrm{Sn}-\mathrm{C}) ; 460 v(\mathrm{Sn}-\mathrm{O})$.

-Synthesis of C5: 1,5-Bis(5-methyl-2-H-3-triphenyltincarboxylate pyrazol) pentane 
The complex $\mathbf{C 5}$ was synthesized in a similar way to that of $\mathbf{C 1}$. (Yield $=58 \%$ ): $\mathrm{mp}=165$ $166^{\circ} \mathrm{C} ;{ }^{1} \mathrm{H}$ NMR (300 MHz, DMSO-d $) \delta: 1.2\left(\mathrm{~m}, 2 \mathrm{H},-\mathrm{C}_{2}-\mathrm{CH}_{2}-\mathrm{CH}_{2}-\mathrm{N}\right) ; 1.66(\mathrm{~m}, 4 \mathrm{H}$, $\left.\mathrm{C}_{2} \mathrm{CH}_{2}-\mathrm{N}\right) ; 2.14\left(\mathrm{~s}, 6 \mathrm{H}, \underline{\mathrm{CH}}_{3}-\mathrm{Pz}\right) ; 3.92\left(\mathrm{t}, 4 \mathrm{H},-\underline{\mathrm{CH}}_{2}-\mathrm{N}\right) ; 6.22(\mathrm{~s}, 2 \mathrm{H}, \underline{\mathrm{H}}-\mathrm{Pz}) ; 7.37-7.93$ (m, 30H,

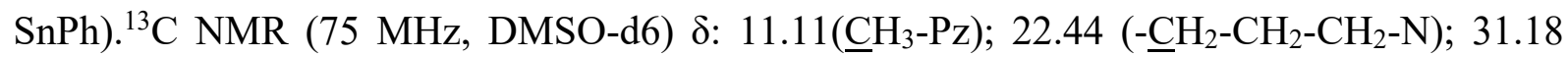
$\left(\underline{\mathrm{C}} \mathrm{H}_{2}-\mathrm{CH}_{2}-\mathrm{N}\right) ; 36.20\left(-\underline{\mathrm{CH}}_{2}-\mathrm{N}\right) ; 108.06(\underline{\mathrm{CH}}-\mathrm{Pz}) ; 139.42\left(\mathrm{CH}_{3}-\underline{\mathrm{C}}=\mathrm{C}\right) ; 143.91(\underline{\mathrm{C}}-\mathrm{C}=\mathrm{O}) ; 162.36$ $(\mathrm{C}=\mathrm{O})$, Sn-phenyl skeleton: $137.23\left(\mathrm{C}_{\mathrm{ipso}}\right) ; 136.79\left(\mathrm{C}_{\text {ortho}}\right) ; 128.81\left(\mathrm{C}_{\text {meta }}\right) ; 129.12\left(\mathrm{C}_{\mathrm{para}}\right)$. IR ( $\left.\mathrm{cm}^{-1}\right): 1624 v_{\mathrm{as}}(\mathrm{COO}) ; 1424 v_{\mathrm{s}}(\mathrm{COO}) ; 530 v(\mathrm{Sn}-\mathrm{C}) ; 450 v(\mathrm{Sn}-\mathrm{O})$.

-Synthesis of C6: 1,6-Bis(5-methyl-2-H-3-triphenyltincarboxylate pyrazol) hexane The complex $\mathbf{C 6}$ was synthesized in a similar way to that of $\mathbf{C 1}$. Yield $=60 \%$; $\mathrm{mp}=189$ $190^{\circ} \mathrm{C} ;{ }^{1} \mathrm{H}$ NMR (300 MHz, DMSO-d 6$) \delta: 1.2\left(\mathrm{~m}, 4 \mathrm{H},-\underline{\mathrm{C}}_{2}-\mathrm{CH}_{2}-\mathrm{CH}_{2}-\mathrm{N}\right) ; 1.65(\mathrm{~m}, 4 \mathrm{H}$, $\left.\mathrm{C}_{2} \mathrm{CH}_{2}-\mathrm{N}\right) ; 2.15$ (s, 6H, $\left.\underline{\mathrm{H}}_{3}-\mathrm{Pz}\right) ; 3.90$ (t, 4H, - $\left.\underline{\mathrm{C}}_{2}-\mathrm{N}\right) ; 6.25$ (s, 2H, $\underline{\mathrm{HPz}}$ ); 7.39-7.93 (m, 30H, $\mathrm{SnPh}) .{ }^{13} \mathrm{C}$ NMR (DMSO-d 6 ) $\delta: 10.72\left(\underline{\mathrm{CH}}_{3}-\mathrm{Pz}\right) ; 29.87\left(-\underline{\mathrm{CH}}_{2}-\mathrm{N}\right) ; 26.24\left(-\underline{\mathrm{CH}}_{2}-\mathrm{CH}_{2}-\mathrm{N}\right) ; 25.39$ $\left(-\underline{\mathrm{CH}_{2}}-\mathrm{CH}_{2}-\mathrm{CH}_{2}-\mathrm{N}\right) ; 108.11(\underline{\mathrm{CH}}-\mathrm{Pz}) ; 143.70\left(\mathrm{CH}_{3}-\underline{\mathrm{C}}=\mathrm{C}\right) ; 145.46(\underline{\mathrm{C}}-\mathrm{C}=\mathrm{O}) ; 166.30(\mathrm{C}=\mathrm{O}), \mathrm{Sn}-$ phenyl skeleton: $139.36\left(\mathrm{C}_{\text {ipso }}\right)$; $136.75\left(\mathrm{C}_{\text {ortho }}\right)$; $128.33\left(\mathrm{C}_{\text {meta }}\right)$; $129.24\left(\mathrm{C}_{\text {para }}\right)$. IR $\left(\mathrm{cm}^{-1}\right)$ : $1640 v_{\mathrm{as}}(\mathrm{COO}) ; 1420 v_{\mathrm{s}}(\mathrm{COO}) ; 530 v(\mathrm{Sn}-\mathrm{C}) ; 450 v(\mathrm{Sn}-\mathrm{O})$.

- Synthesis of C7: Bis (2-(methyl-2-H-3-triphenyltincarboxylate pyrazol) ethyl) oxide The complex $\mathbf{C 7}$ was synthesized in a similar way to that of $\mathbf{C 1}$. Suitable colorless crystals were obtained by a slow evaporation of solvent. (Yield $=65 \%): \mathrm{mp}=206-207^{\circ} \mathrm{C} ;{ }^{1} \mathrm{H}$ NMR(300 MHz, DMSO-d $)$ ) $: 2.10$ (s, 6H, $\left.\underline{\mathrm{H}}_{3}-\mathrm{Pz}\right) ; 3.6$ (t, 4H, - $\left.\underline{\mathrm{H}}_{2}-\mathrm{N}\right) ; 4.03$ (t, 4H, - $\mathrm{OC}_{2}-$ $\left.\mathrm{CH}_{2}-\mathrm{N}\right) ; 6.25$ (s, 2H, $\left.\underline{\mathrm{H}}-\mathrm{Pz}\right) ; 7.19-7.93$ (m, 30H, SnPh). ${ }^{13} \mathrm{C}$ NMR (75 MHz, DMSO-d $)$

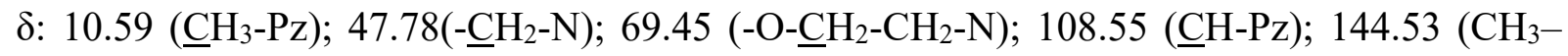
$\underline{\mathrm{C}}=\mathrm{C}) ; 143.97(\underline{\mathrm{C}}-\mathrm{C}=\mathrm{O}) ; 168.17(\mathrm{C}=\mathrm{O})$, Sn-phenyl skeleton: $138.38\left(\mathrm{C}_{\mathrm{ipso}}\right) ; 136.47\left(\mathrm{C}_{\text {ortho }}\right)$; $128.71\left(\mathrm{C}_{\text {meta }}\right) ; 130.13\left(\mathrm{C}_{\text {para }}\right) . \mathrm{IR}\left(\mathrm{cm}^{-1}\right): 1650 v_{\mathrm{as}}(\mathrm{COO}) ; 1400 v_{\mathrm{s}}(\mathrm{COO}) ; 530 v(\mathrm{Sn}-\mathrm{C}) ; 460$ $v(\mathrm{Sn}-\mathrm{O})$ 


\subsection{X-ray crystallography}

A pale yellow triangular crystal of $\mathbf{C} \mathbf{3}$ and a colorless parallelepiped crystal of $\mathbf{C} 7$ were selected under a stereo microscope with a polarizing filter to be used for X-ray diffraction data collection at $173 \mathrm{~K}$. The intensities were measured on a Bruker D8 Venture 4-circle diffractometer equipped with an Incoatec $\mathrm{I} \mu \mathrm{S} 3.0 \mathrm{Mo}$ microsource $(110 \mu \mathrm{m}$ beam, $\mathrm{K} \alpha$ radiation $\lambda=0.71073$ $\AA$ ) and a Photon II CPAD detector. Cell refinement, data reduction and Lorentz-polarization corrections were performed using the Apex software suite [29] and the reflections were corrected for absorption effects (multi-scan SADABS).

Table 1. Crystal data and refinement parameters

\section{C3}

$\mathrm{C}_{49} \mathrm{H}_{44} \mathrm{~N}_{4} \mathrm{O}_{4} \mathrm{Sn}_{2}$

$990.26,2$

173(2)

Monoclinic, P2 1 (4)

15.916(1)

$\mathrm{V}\left(\AA^{3}\right)$

Calculated density (Mg.m $\left.{ }^{-3}\right)$

No. of unique reflections, $R_{\text {int }}$

$R\left[F^{2}>2 \sigma\left(F^{2}\right)\right], w R\left(F^{2}\right)[\mathrm{I}>2 \sigma(\mathrm{I})]$

$R\left[F^{2}>2 \sigma\left(F^{2}\right)\right], w R\left(F^{2}\right)$ (all data)

$\Delta \rho_{\max }, \Delta \rho \min \left(\mathrm{e} . \AA^{-3}\right)$
C7

$\mathrm{C}_{50} \mathrm{H}_{46} \mathrm{~N}_{4} \mathrm{O}_{5} \mathrm{Sn}_{2}$
173(2)

Monoclinic, $\mathrm{P} 2{ }_{1} / \mathrm{n}$ (14)
10.0791(8)

13.823(1)

100.459(3)

2180.7(3)

15.0951(7)

8.9847(3)

34.244(1)

101.421(2)

4552.4(3)

1.508

1.489

23447, 0.0473

$17932,0.0515$

$0.0303,0.0820$

$0.0401,0.0917$

$0.0437,0.0934$

$0.0512,0.0995$

$1.618 /-1.223$ 
The structures were solved and refined by full-matrix least-squares on $\mathrm{F}^{2}$ using the SHELX programs [30-31]. Positional and anisotropic displacement parameters were refined for all non$\mathrm{H}$ atoms. Either detected in the final Fourier difference or generated at idealized positions, the $\mathrm{H}$ atom coordinates were treated in the refinements using AFIX instructions and displacement parameters equal to 1.2 times $\left(1.5\right.$ for $\left.-\mathrm{CH}_{3}\right)$ the $\mathrm{U}_{\text {eq }}$ of the parent atom. The main crystal data and refinement parameters are given in Table 1 and full CIF file can be freely obtained from the Cambridge Crystallographic Data Center mentioning the CCDC numbers 2013128 (C3) and 2013129 (C7). The structure representations have been drawn using ORTEP-3 for Windows [32].

\subsection{Antifungal Activity}

The in vitro antifungal activity of the ditriphenyltin(IV) dicarboxylate complexes and their corresponding pyrazolic dicarboxylic acid (ligands) was evaluated against the pathogen fungus Fusarium oxysporum f. sp. albedinis (FAO) using the agar diffusion technique [3334]. Potato dextrose agar (PDA) medium was mixed with different volumes $(40,160$, and $500 \mu \mathrm{L})$ of a DMSO solution of the tested compounds. Then, discs of $6 \mathrm{~mm}$ in diameter of the microorganism (FAO) were placed into the middle of these Petri plates. After an incubation at $28^{\circ} \mathrm{C}$ for 7 days, inhibition percentages were calculated and the half maximal inhibitory concentration $\left(\mathrm{IC}_{50}\right)$ was determined using a nonlinear regression algorithm of the dose-inhibition percentage graph. The inhibition percentage (\% I) of the growth rate was calculated using the following formula:

$$
\% \mathrm{I}=((\mathrm{Do}-\mathrm{Dx}) / \mathrm{Do}) \times \mathbf{1 0 0},
$$

where Do and Dx are the diameters $(\mathrm{cm})$ of the FOA in absence and in presence of the product tested, respectively. Benomyl was used as positive control. 


\section{Discussion}

\subsection{Synthesis of C1-C7}

The elaboration of the target compounds C1-C7 was performed as showed in the Scheme 1 . Bipyrazolic ester compounds 1-7 were first synthesized and then converted to their corresponding acid derivatives L1-L7 using a simple hydrolysis reaction in alkaline medium as reported in our previous works [22-23, 25-28]. The structure of these intermediate compounds was checked by spectroscopic and spectrometric methods. Thereafter, the synthesis of tin complexes C1-C7 was achieved by condensing one equivalent of L1-L7 with two equivalents of triphenyltin hydroxide in toluene. Nevertheless, this kind of reaction could lead to another second product due to the $1+1$ condensation (Fig. 2). Thus, ${ }^{1} \mathrm{H}$ NMR spectroscopy was used to overcome the ambiguity around structures of the resulting complexes. Indeed, the distinction between the complexes resulting from $1+1$ and $1+2$ condensation can be performed, based on integrals of phenyl groups and alkyl spacer centered at 0.5-2 and 7-8 ppm, respectively. According to these shifts, it was confirmed that all the formed products were obtained from the $2+1$ condensation.

Furthermore, the structure of complexes $\mathbf{C 3}$ and $\mathbf{C 7}$ were ensured by X-ray crystallographic analysis carried out on single crystals obtained by recrystallization of these compounds from toluene.

\subsection{Spectroscopic characterization of complexes C1-C7}

The IR spectra of complexes C1-C7 were recorded in the range 4000-400 $\mathrm{cm}^{-1}$. We note the absence of large band in the range of $3400-2800 \mathrm{~cm}^{-1}$ assigned to $\mathrm{O}-\mathrm{H}$ stretching vibrations and the presence of strong bands at 440-449 $\mathrm{cm}^{-1}$ attributed to the $v(\mathrm{Sn}-\mathrm{O})$ vibration mode [29-31]. This indicates a Sn-O coordinated structure and also evidences the formation of complexes due to the $2+1$ condensation. The characteristic bands corresponding to $v(\mathrm{C}=\mathrm{C})$ and $v(\mathrm{C}=\mathrm{N})$ 
vibrations of the pyrazolic ring were found in the range $1578-1537 \mathrm{~cm}^{-1}$, while the stretching frequency associated with Sn-C bond occurs in the $556-587 \mathrm{~cm}^{-1}$ region. In addition, an intense band situated at $1100 \mathrm{~cm}^{-1}$ was observed in the FTIR spectrum of $\mathbf{C 7}$, which corresponds to the C-O vibration of the aliphatic chain, while the strong absorption bands that appear at 1588-1650 and $1335-1433 \mathrm{~cm}^{-1}$ are assigned to the asymmetric and symmetric vibrations of the COO moiety (Fig. 3). Furthermore, the difference between asymmetric and symmetric $\mathrm{O}-\mathrm{C}=\mathrm{O}$ stretching vibrations, namely $\Delta v=v_{\text {as }}(\mathrm{OCO})-v_{\mathrm{s}}(\mathrm{OCO})$ has already been used to determine the mode of coordination of a carboxylate ligand with metals [19], thus this difference $\Delta v$ shecan give information about the chelating mode of the carboxylate group. Differences larger than $250 \mathrm{~cm}^{-1}$ are typical of monodentate complexes, while $\Delta v$ values in the range of $150-250 \mathrm{~cm}^{-1}$ are indicative of compounds with carboxylate bridged structures. Instead a difference lower than $150 \mathrm{~cm}^{-1}$ is assigned to chelated structures. For the compounds $\mathbf{C 1 - C 7}$, the $\Delta v$ values are as follows: 252, 250, 220, 240, 230, 210 and 200, respectively. These differences between the asymmetric and symmetric stretching frequencies of the coordinated carboxyl group lie in the range $250-200 \mathrm{~cm}^{-1}$, suggesting a monodentate coordination for the carboxylic moiety [35-36] as is also proved by the X-ray crystal structures. The absorption bands which appear in frequency ranges $484-443 \mathrm{~cm}^{-1}$ and $575-523 \mathrm{~cm}^{-1}$ for the synthesized compounds are assigned respectively to $\mathrm{Sn}-\mathrm{O}$ and $\mathrm{Sn}-\mathrm{C}$ bonds, which also supports the formation of complexes [35-36]. These results suggest that the tin atom in each of the triorganotin(IV) species approaches fivecoordination. The electronic absorption spectra of these compounds were also recorded in methylene chloride using UVVisible spectroscopy. All the spectra (Fig. 4) are quite similar and exhibit absorption peaks in the region $242-246 \mathrm{~nm}$ resulting from the $\pi \rightarrow \pi^{*}$ and the $\mathrm{n} \rightarrow \pi^{*}$ transitions [27]. 


\subsection{NMR Spectroscopy}

As expected, the proton NMR spectra of C1-C7 complexes display the same integration and peak multiplicities compared to those of the free ligands. The only difference is the absence of peaks at the range $\approx 12.00-13.50 \mathrm{ppm}$ corresponding to protons of the carboxylic COOH moiety which was substituted by the six phenyl groups appeared at the range $\approx 7-8 \mathrm{ppm}$. This stands for the coordinating of carboxylate groups to Sn atoms and also evidence the formation of complexes resulting from $1+2$ condensation as reported above.

Concerning the ${ }^{13} \mathrm{C}$ NMR, the same remarks were observed. In fact, the chemical shifts for the tin (IV) complexes were found to be similar to those of the free ligand L1-L7, except the appearance of four peaks attributed to the phenyl group and carboxylate carbons, which move to the lower field due to the electron density transfer from the ligand to the acceptor Sn atoms [37]. This indicates the carboxylic groups coordinate to tin (IV).

\subsection{Crystal structures of $\mathrm{C} 3$ and $\mathrm{C} 7$}

Among the seven compounds C1-C7 studied in this work, only two were obtained in the form of crystals of suitable quality for an X-ray diffraction study. These are compounds $\mathbf{C} \mathbf{3}$ and $\mathbf{C 7}$, namely: 1,3-Bis[5-methyl-2-H-3-triphenyltincarboxylate pyrazol]propane and Bis[2-methyl2H-3-triphenyltincarboxylate pyrazol]ethyl oxide. Single crystal study led us to solve the structure of compound $\mathbf{C} 3$ in the monoclinic space group $\mathrm{P} 2{ }_{1}$. The unit cell contains two molecules of formula $\mathrm{C}_{49} \mathrm{H}_{44} \mathrm{~N}_{4} \mathrm{O}_{4} \mathrm{Sn}_{2}$. These molecules can be viewed as constituted of two fragments $\mathrm{Ph}_{3} \mathrm{Sn}\left(\mathrm{C}_{6} \mathrm{H}_{6} \mathrm{~N}_{2} \mathrm{O}_{2}\right)$, otherwise formulated: (5-methyl-1-H-3-triphenyltincarboxylate pyrazol) methyl, that are connected through a central carbon atom, labeled C7 in the molecular representation given in Fig. 5. The molecule of $\mathbf{C 3}$ is characterized with two tetra coordinated tin atoms. The bond lengths and angles involving the metal atoms, given in Table 2, slightly differ for the two cristallographically independent $\mathrm{Sn} 1$ and $\mathrm{Sn} 2$ atoms and indicate distorted geometries for the corresponding tetrahedral environments. 
Table 2. Geometric characteristics (bonds, $\AA$ and angles, ${ }^{\circ}$ ) around tin atoms in $\mathbf{C 3}$.

\begin{tabular}{cccc}
\hline $\mathrm{Sn} 1-\mathrm{O} 2$ & $2.066(3)$ & $\mathrm{Sn} 2-\mathrm{O} 4$ & $2.079(3)$ \\
$\mathrm{Sn} 1-\mathrm{C} 14$ & $2.121(5)$ & $\mathrm{Sn} 2-\mathrm{C} 32$ & $2.115(5)$ \\
$\mathrm{Sn} 1-\mathrm{C} 20$ & $2.130(5)$ & $\mathrm{Sn} 2-\mathrm{C} 44$ & $2.115(5)$ \\
$\mathrm{Sn} 1-\mathrm{C} 26$ & $2.141(4)$ & $\mathrm{Sn} 2-\mathrm{C} 38$ & $2.134(5)$ \\
$\mathrm{O} 2-\mathrm{Sn} 1-\mathrm{C} 14$ & $109.6(2)$ & $\mathrm{O} 4-\mathrm{Sn} 2-\mathrm{C} 32$ & $108.2(2)$ \\
$\mathrm{O} 2-\mathrm{Sn} 1-\mathrm{C} 20$ & $96.3(2)$ & $\mathrm{O} 4-\mathrm{Sn} 2-\mathrm{C} 44$ & $109.3(2)$ \\
$\mathrm{C} 14-\mathrm{Sn} 1-\mathrm{C} 20$ & $112.8(2)$ & $\mathrm{C} 32-\mathrm{Sn} 2-\mathrm{C} 44$ & $120.2(2)$ \\
$\mathrm{O} 2-\mathrm{Sn} 1-\mathrm{C} 26$ & $108.0(2)$ & $\mathrm{O} 4-\mathrm{Sn} 2-\mathrm{C} 38$ & $95.9(2)$ \\
$\mathrm{C} 14-\mathrm{Sn} 1-\mathrm{C} 26$ & $120.2(2)$ & $\mathrm{C} 32-\mathrm{Sn} 2-\mathrm{C} 38$ & $107.4(2)$ \\
$\mathrm{C} 20-\mathrm{Sn} 1-\mathrm{C} 26$ & $107.3(2)$ & $\mathrm{C} 44-\mathrm{Sn} 2-\mathrm{C} 38$ & $113.0(2)$ \\
\hline
\end{tabular}

The molecules are arranged in the crystal as shown in Fig. 6 representing the structure projection along the unique b-axis of the monoclinic cell. As the molecule contains polar covalent bonds, some electrostatic interactions involving the polar centers may occur thus stabilizing effects are expected in the crystal due to weak van der Waals interactions or hydrogen bonding. The X-ray crystal structure of compound $\mathbf{C} 7$ was solved and refined in the monoclinic space group $\mathrm{P} 2{ }_{1} / \mathrm{n}$. The unit cell contains four molecules of formula $\mathrm{C}_{50} \mathrm{H}_{46} \mathrm{~N}_{4} \mathrm{O}_{5} \mathrm{Sn}_{2}$. Some disorder has been found both at one pyrazole and two phenyl cycles.

For clarity, the alternate positions of the disordered atoms are drawn in Fig. 7 using the styles "boundary" for ellipsoids and "open" for bonds and, in addition, a unique label is indicated for the disordered atoms.

Table 3. Geometric characteristics (bonds, $\AA$ and angles, ${ }^{\circ}$ ) around tin atoms in C7.

$\begin{array}{cccc}\mathrm{Sn} 1-\mathrm{O} 1 & 2.076(1) & \mathrm{Sn} 2-\mathrm{O} 3 & 2.058(2) \\ \mathrm{Sn} 1-\mathrm{C} 1 & 2.118(2) & \mathrm{Sn} 2-\mathrm{C} 45 & 2.114(2) \\ \mathrm{Sn} 1-\mathrm{C} 13 & 2.120(2) & \mathrm{Sn} 2-\mathrm{C} 33 & 2.121(2) \\ \mathrm{Sn} 1-\mathrm{C} 7 & 2.131(2) & \mathrm{Sn} 2-\mathrm{C} 39 & 2.134(2)\end{array}$




$\begin{array}{cccc}\mathrm{O} 1-\mathrm{Sn} 1-\mathrm{C} 1 & 117.82(7) & \mathrm{O} 3-\mathrm{Sn} 2-\mathrm{C} 45 & 104.36(7) \\ \mathrm{O} 1-\mathrm{Sn} 1-\mathrm{C} 13 & 104.55(6) & \mathrm{O} 3-\mathrm{Sn} 2-\mathrm{C} 33 & 117.52(8) \\ \mathrm{C} 1-\mathrm{Sn} 1-\mathrm{C} 13 & 116.84(7) & \mathrm{C} 45-\mathrm{Sn} 2-\mathrm{C} 33 & 116.99(8) \\ \mathrm{O} 1-\mathrm{Sn} 1-\mathrm{C} 7 & 96.45(7) & \mathrm{O} 3-\mathrm{Sn} 2-\mathrm{C} 39 & 95.93(8) \\ \mathrm{C} 1-\mathrm{Sn} 1-\mathrm{C} 7 & 107.22(7) & \mathrm{C} 45-\mathrm{Sn} 2-\mathrm{C} 39 & 109.77(9) \\ \mathrm{C} 13-\mathrm{S} 1-\mathrm{C} 7 & 112.23(8) & \mathrm{C} 33-\mathrm{S} n 2-\mathrm{C} 39 & 110.14(8)\end{array}$

As for $\mathbf{C 3}$, the $\mathbf{C} 7$ molecule can be considered with two fragments (triphenyltin): 2-(5-methyl2H-3-triphenyltincarboxylate pyrazol) ethyl, linked together via an oxygen atom labelled O5 in Fig. 7. Even if the nature of the central atom is changed, here it is oxygen instead of a carbon, and if the fragments differ in the length of their carbon chains, the molecules of $\mathbf{C} \mathbf{3}$ and $\mathbf{C 7}$ have a great resemblance. Here too, the two cristallographically independent $\mathrm{Sn} 1$ and $\mathrm{Sn} 2$ atoms are tetra coordinated within distorted tetrahedral environments. The distances and angles around tin atoms given in Table 3 are very similar to those found for the molecule of C3. Furthermore, they are in the usual ranges reported for similar compounds [37-39].

The arrangement of molecules in the crystal lattice has been represented in Fig. 8. The hydrogen bonding which contributes to the stabilization of $\mathbf{C 7}$ in the solid state has been underlined with the drawing (orange dashed lines) of the weak interactions between polar centers and the surrounding atoms.

\subsection{Antifungal activity}

The organotin compounds C1-C7 and their corresponding ligands L1-L7 have been evaluated in vitro for their antifungal potency against Fusarium oxysporum f. sp. Albedinis (FOA). The obtained results are presented in Fig. 9 and in Table 4, where "strain diameter" represents the diameter of the FOA strain placed in presence of the tested compound. 
Table 4. Results of antifungal activity for C1-C7 complexes and their L1-L7 ligands.

\begin{tabular}{|c|c|c|c|c|c|}
\hline Compound & Structure & $\begin{array}{c}\text { Volume } \\
\text { withdrawn } \\
(\mu \mathrm{l})\end{array}$ & $\begin{array}{c}\text { Strain } \\
\text { diameter }(\mathrm{cm})\end{array}$ & $\begin{array}{c}\text { Inhibition } \\
\%\end{array}$ & $\begin{array}{l}\mathrm{IC}_{50} ; \mu \mathrm{M} ; \\
\left(\mu \mathrm{g} \cdot \mathrm{mL}^{-1}\right)\end{array}$ \\
\hline \multirow{3}{*}{ C1 } & & 40 & 6 & 29.41 & \multirow{3}{*}{$49.8 ;(48)$} \\
\hline & & 160 & 3 & 64.71 & \\
\hline & & 500 & 0 & 100.00 & \\
\hline \multirow{3}{*}{$\mathrm{C} 2$} & & 40 & 8.5 & 0.00 & \multirow[b]{3}{*}{-} \\
\hline & & 160 & 6.6 & 22.35 & \\
\hline & & 500 & 0 & 100.00 & \\
\hline \multirow{3}{*}{ C3 } & & 40 & 8.5 & 0.00 & \multirow[b]{3}{*}{-} \\
\hline & & 160 & 6.3 & 25.88 & \\
\hline & & 500 & 0 & 100.00 & \\
\hline \multirow{3}{*}{$\mathrm{C} 4$} & & 40 & 8,5 & 0.00 & \multirow{3}{*}{-} \\
\hline & & 160 & 6,4 & 24.74 & \\
\hline & & 500 & 0 & 100.00 & \\
\hline \multirow{3}{*}{ C5 } & & 40 & 6.8 & 20.00 & \multirow{3}{*}{$39.2 ;(40)$} \\
\hline & & 160 & 1.7 & 80.00 & \\
\hline & & 500 & 0 & 100.00 & \\
\hline \multirow{3}{*}{ C6 } & & 40 & 8.5 & 0.00 & \multirow{3}{*}{-} \\
\hline & & 160 & 6 & 29.41 & \\
\hline & & 500 & 0. & 100.00 & \\
\hline \multirow{3}{*}{ C7 } & & 40 & 8.5 & 0.00 & \\
\hline & & 160 & 6.7 & 21.18 & \\
\hline & & 500 & 0 & 100.00 & - \\
\hline \multirow{3}{*}{ L1 } & & 40 & 8.5 & 0.00 & \\
\hline & & 160 & 8.5 & 0.00 & \\
\hline & & 500 & 1 & 88.24 & - \\
\hline \multirow{3}{*}{ L2 } & & 40 & 8.5 & 0.00 & \\
\hline & & 160 & 8.5 & 0.00 & \\
\hline & & 500 & 1.2 & 85.88 & - \\
\hline \multirow{3}{*}{ L3 } & & 40 & 8.5 & 0.00 & \\
\hline & & 160 & 8.5 & 0.00 & \\
\hline & & 500 & 1.4 & 83.53 & - \\
\hline \multirow{3}{*}{ L4 } & & 40 & 8.5 & 0.00 & \\
\hline & & 160 & 8.5 & 0.00 & \\
\hline & & 500 & 0.7 & 91.76 & - \\
\hline \multirow{3}{*}{ L5 } & & 40 & 8.5 & 0.00 & \multirow{3}{*}{ - } \\
\hline & & 160 & 8.5 & 0.00 & \\
\hline & & 500 & 1.6 & 81.18 & \\
\hline \multirow{3}{*}{ L6 } & & 40 & 8.5 & 0.00 & . \\
\hline & & 160 & 8.5 & 0.00 & \\
\hline & & 500 & 1.4 & 83.53 & - \\
\hline \multirow{3}{*}{ L7 } & & 40 & 8.5 & 0.00 & \\
\hline & & 160 & 8.5 & 0.00 & \\
\hline & & 500 & 7.9 & 7.06 & \\
\hline \multirow{3}{*}{ Benomyl(reference) } & & 40 & 2,3 & 54 & 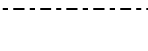 \\
\hline & & 160 & 1,1 & 78 & \\
\hline & & 500 & 0,3 & 94 & - \\
\hline
\end{tabular}


It is clear, that the antifungal activity depends on the dose used. Indeed, all bipyrazolic ligands L1-L7 are inactive against the FOA at the volume with draw of 40 and 160 1. An increase in this volume to $500 \mu \mathrm{l}$ leads to an increase in the inhibition percentage for compounds bearing alkyl chains (L1-L6) which become in the range of 83.53-91.76. Besides, at this same volume, replacing the pentyl chain in $\mathbf{L 5}$ by diethyl ether decreases dramatically the antifungal activity and lead to $\mathbf{L} 7$ compound without any antifungal potency. These results evidenced that, contrary to its nature, the length of the alkyl chain has a little effect on the antifungal potency of such compounds. In fact, these two parameters could modify the conformation of the ligands in the space and thus affect the position of the pharmacophore sites able to interact with the target fungus. Nevertheless, the activity of these molecules remains lower than that of the positive control, Benomyl.

Attaching the triphenyltin moiety to ligand L1-L6 markedly increases the antifungal activity, the inhibition percentage reaches then $100 \%$ for the six complexes and is higher than for benomyl fungicide at $500 \mu$ l. However, some differences exist in the values obtained at 40 and $160 \mu$ l. Interestingly, the ligand $\mathbf{L} 7$ with practically no antifungal activity becomes potent after being tethered to the triphenyltin group. These results demonstrate that when passing from ligands to their tin(IV) complexes, in addition to the introduction of triphenyltin, the length and the nature of the chain linking the two pyrazolic rings still influence the antifungal potency. It should be noted, that these results agree well with those reported by the literature $[8,9]$. These authors figured out that organic groups attached in the $\operatorname{Sn}(\mathrm{IV})$ derivatives affect the biological activity of their organotin complexes towards some fungal strains and stated that the activity increases in the order: $\mathrm{Ph}_{3}>\mathrm{Bu}_{2}>\mathrm{Cl}_{2}>\mathrm{Ph}_{2}>\mathrm{Ph}$. On the other hand, the high antifungal activity of our tin complexes might be explained by their lipid-solubility $[8,9,41]$ that allows them to cross the cytoplasmic membrane and then become a possible site of action [41-42]. Thus, the present organotin complexes C1-C7 might be valorized as new anti-FOA family drugs, 
especially $\mathbf{C 1}$ and $\mathbf{C 5}$ with $\mathrm{IC}_{50} 49.8$ and $39.2 \mu \mathrm{M}$, respectively. These complexes can be used alone or in a formulation with others products.

\section{Conclusion}

During the present work, we have synthesized and characterized seven new bipyrazoletriorganotin dicarboxylate, which differ by the nature and the length of spacers between the two pyrazole rings. The single crystal X-ray structure has been determined for both compounds $\mathbf{C 3}$ and $\mathbf{C 7}$. The results of antifungal tests against Fusarium oxysporum f. sp. albedinis (FOA) show a higher antifungal activity for the organotin pyrazole compounds than for Benomyl, the reference fungicide. This activity has been shown to depend on (i) the presence of tin as a metal atom in the structure; (ii) the nature and the length of the chain linking the two pyrazolic rings of the ligands; (iii) the presence of triphenyltin moiety and (iv) the dose used. Although all tin (IV) complexes showed good antifungal activity,it is likely that complexes $\mathbf{C 1}$ and $\mathbf{C 5}$ can be developed as new anti-FOA fungicides for uses alone or in formulation with other chemicals.

\section{Conflicts of interest}

No conflict of interest was reported by the authors.

\section{Appendix A. Supplementary data}

CCDC $<2013128>$ for $\mathrm{C}_{49} \mathrm{H}_{44} \mathrm{~N}_{4} \mathrm{O}_{4} \mathrm{Sn}_{2}(\mathbf{C} 3)$ and $\mathrm{CCDC}<2013129>$ for $\mathrm{C}_{50} \mathrm{H}_{46} \mathrm{~N}_{4} \mathrm{O}_{5} \mathrm{Sn}_{2}(\mathbf{C} 7)$ deposited CIF files contain the full crystallographic data for the title compounds. These data can be obtained free of charge via http://www.ccdc.cam.ac.uk/conts/retrieving.html, or from the Cambridge Crystallographic Data Centre, 12 Union Road, Cambridge CB2 1EZ, UK; fax: (+44) 1223-336-033; or e-mail: deposit@ccdc.cam.ac.uk. 


\section{References}

[1] M. Gielen, Tin-based antitumor drugs, Coord. Chem. Rev. 151 (1996) 41-51. https://doi.org/10.1016/S0010-8545(96)90193-9

[2] M. S. Ahmad, M. Hussain, M. Hanif, S. Ali, B. Mirza, Synthesis, chemical characterization and biological screening for cytotoxicity and antitumor activity of organotin (IV) derivatives of 3, 4-methylenedioxy 6-nitrophenylpropenoic acid, Molecules. 12(10) (2007) 2348-2363. https://doi.org/10.3390/12102348

[3] E. R. Tiekink, Structural chemistry of organotin carboxylates: a review of the crystallographic literature, Appl. Organomet. Chem. 5(1) (1991) 1-23.

https://doi.org/10.1002/aoc.590050102

[4] C. E. Carraher Jr, M. R. Roner, Organotin polymers as anticancer and antiviral agents, J. Organomet. Chem. 751 (2014) 67-82.

https://doi.org/10.1016/j.jorganchem.2013.05.033

[5] C. E. Carraher, T. S. Sabir, M. R. Roner, K. Shahi, R. E. Bleicher, J. L. Roehr, K. D. Bassett, Synthesis of organotin polyamine ethers containing acyclovir and their preliminary anticancer and antiviral activity, J. Inorg. Organomet.Polym.Mater. 16(3) (2006) 249-257.

https://doi.org/10.1007/s10904-006-9050-y

[6] L. Hu, H. Wang, T. Xia, B. Fang, Y. Shen, Q. Zhang, Y. Tian, Two-Photon-Active Organotin (IV) Complexes for Antibacterial Function and Superresolution Bacteria Imaging, Inorg. Chem. 57(11) (2018) 6340-6348. https://doi.org/10.1021/acs.inorgchem.8b00413

[7] T. Sedaghat, , M. Yousefi, , G. Bruno, , H. A. Rudbari, , H.Motamedi, V. Nobakht, Synthesis, spectral characterization, crystal structure and antibacterial studies of diorganotin (IV) complexes with isonicotinoylhydrazone derivatives, Polyhedron. 79 (2014) 88-96. https://doi.org/10.1016/j.poly.2014.04.061

[8] D. C. Menezes, , F. T. Vieira, G. M. De Lima, , J. L. Wardell, , M. E. Cortés, , M. P. Ferreira, A. Vilas Boas, The in vitro antifungal activity of some dithiocarbamateorganotin (IV) compounds on Candida albicans - a model for biological interaction of organotin complexes, Appl. Organomet. Chem. 22(4) (2008) 221-226. 
https://doi.org/10.1002/aoc. 1375

[9] E. N. Iornumbe, S. G. Yiase, J. Audu, B. O. Ozide, Comparative analyse of antifungal property of some organotin (IV) derivatives of ethanedioic acid and butanedioic acid with active centres, Journal of Chemical Society of Nigeria. 43(4) (2018).

[10] M.Nath, R. Yadav, M. Gielen, H. Dalil, D. de Vos, G. Eng, Synthesis, characteristic spectral studies and in vitro antimicrobial and antitumour activities of organotin (IV) complexes of Schiff bases derived from amino_acids, Appl. Organomet. Chem. 11(9) (1997) 727-736. https://doi.org/10.1002/(SICI)1099-0739(199709)11:9<727::AIDAOC639>3.0.CO;2-X.

[11] D. Kovala-Demertzi, V. Dokorou, A. Primikiri, R. Vargas, C. Silvestru, U. Russo, M. A. Demertzis, Organotin meclofenamic complexes: synthesis, crystal structures and antiproliferative activity of the first complexes of meclofenamic acid-novel antituberculosis agents, J. Inorg. Biochem. 103(5) (2009) 738-744. https://doi.org/10.1016/j.jinorgbio.2009.01.014

[12] M. Nath, M. Vats, P. Roy, Design, spectral characterization, anti-tumor and antiinflammatory activity of triorganotin (IV) hydroxycarboxylates, apoptosis inducers: in vitro assessment of induction of apoptosis by enzyme, DNA-fragmentation, acridine orange and comet assays, Inorgan. Chim.Acta. 423 (2014) 70-82.

https://doi.org/10.1016/j.ica.2014.02.034

[13] A. Corona-Bustamante, J. M. Viveros-Paredes, A. Flores-Parra, A. L. Peraza-Campos, F. J. Martínez-Martínez, M. T.Sumaya-Martínez, Á. Ramos-Organillo, Antioxidant activity of butyl-and phenylstannoxanes derived from 2-, 3-and 4-pyridinecarboxylic acids, Molecules.

15 (8) (2010) 5445-5459. https://doi.org/10.3390/molecules15085445

[14] T. R. Gordon, Fusariumoxysporum and the Fusarium Wilt Syndrome, Annu. Rev.

Phytopathol. 55 (1) (2017) 23-39. https://doi.org/10.1146/annurev-

phyto-080615-095919

[15] J. G. A. Luijten, Applications and biological effects of organotin compounds. Organotin compounds, 3 (1972) 931-974. 
[16] G. D. Van Kerk, J. G. A. Luijten, Investigations on organo_tin compounds. III. The biocidal properties of organo_tin compounds, J. Appl. Chem. 4(6) (1954) 314-319.

https://doi.org/10.1002/jctb.5010040607

[17] A. K. Sijpesteijn, F. Rijkens, J. G. A. Luijten, L. C. Willemsens, on the antifungal and antibacterial activity of some trisubstitutedorganogermanium, organotin and organolead compounds, Anton. Leeuw. INT. J. G. 28(1) (1962) 346-356.

https://doi.org/10.1007/BF02538746

[18] K. Hartel, Triphenyltin compounds, Agr. Vet. Chem. 3 (1962) 19-24.

[19] A. Dutrecq, R. Willem, M. Biesemans, M. Boualam, A. Et-Touhami(ex-Meriem), M. Gielen, Toxicity of a series of tri-and diorganotin (IV) compounds against phytogenic fungal and bacterial lines, Main Group Met. Chem. 15 (1992) 285-291.

[20] A. Yahyi, A. Et-Touhami, S. Radi, I. Zidane, A. Hakkou, M. Bouakka, Synthesis and biological activities of new triphenylorganotin (IV) based on the pyrazole carboxylic acids, Lett. Drug Des.Discov. 4(5) (2007) 382-385.

https://doi.org/10.2174/157018007780867889

[21] T. Harit, H. Abouloifa, M. Tillard, D. Eddike, A. Asehraou, F. Malek, New copper complexes with bipyrazolic ligands: Synthesis, characterization and evaluation of the antibacterial and catalytic properties, J. Mol. Struc. 1163 (2018) 300-307.

https://doi.org/10.1016/j.molstruc.2018.03.008

[22] S. Radi, A. Yahyi, A. Et-Touhami, A. C. Jha, N. N. Adarsh, K. Robeyns, Y. Garcia, Synthesis and crystal structures of mononuclear CuII/CoII coordination complexes from pyrazole-dicarboxylate acid derivatives, Polyhedron. 85 (2015) 383-388.

https://doi.org/10.1016/j.poly.2014.08.059

[23] S. Radi, M. El-Massaoudi, H. Benaissa, N. N. Adarsh, M. Ferbinteanu, E. Devlin, Y. Sanakis, Y. Garcia, Crystal engineering of a series of complexes and coordination polymers based on pyrazole-carboxylic acid ligands, New Journal of Chemistry. 41(16) (2017) 82328241. https://doi.org/10.1039/C7NJ01714F 
[24] V. Chandrasekhar, R. Thirumoorthi, Reactions of 3, 5-pyrazoledicarboxylic acid with organotin chlorides and oxides.Coordination polymerscontainingorganotin macrocycles, Organometallics. 28(7) (2009) 2096-2106.

https://doi.org/10.1021/om8011739

[25] F. Malek, M. Persin, A. Ramdani, J. Sarrazin, I. Zidane, Elaboration de nouveaux matériaux membranaires incorporant des macrocycles tetrapyrazoliques. Etude du transport facilité des métaux alcalins $\mathrm{Li}^{+}, \mathrm{Na}^{+}$et $\mathrm{K}^{+}$, New J. Chem.

$26(2002) 876-882$.

https://doi.org/10.1039/B110617C

[26] T. Harit, M. Cherfi, H. Abouloifa, J. Isaad, I. Bouabdallah, M. Rahal, A. Asehraou, F.

Malek,Synthesis, Characterization, Antibacterial Properties and DFT Studies of Two New

PolypyrazolicMacrocycles, $\quad$ Polycycl. Aromat.Compd. $\quad$ (2018) 1-11. https://doi.org/10.1080/10406638.2018.1555175

[27] T. Harit, M. Dahmani, S. Gaamouche, F. Malek, M. Dusek, A. Manseri, A. Asehraou, New bipyrazolic compounds: Synthesis, characterization, antibacterial activity and computational studies, J. Mol. Struc. 1176 (2019) 110-116.

https://doi.org/10.1016/j.molstruc.2018.08.073

[28] T. Harit, F. Malek, B. El Bali, M. Dusek, M. Kucerakova, Synthesis and characterization of two new tetrapyrazolicmacrocycles for the selective extraction of cesium cation, Tetrahedron, 72 (2016) 3966-3973.

https://doi.org/10.1016/j.tet.2016.05.026

[29] Bruker, APEX3. Version 2017.3-0, Bruker AXS, Inc., Madison, Wisconsin, USA [30] G. M. Sheldrick, Crystal structure refinement with SHELXL, ActaCryst. C71 (2015) 3-8. https://doi.org/10.1107/S2053229614024218

[31] G. M. Sheldrick, SHELXT- Integrated space-group and crystal-structure determination, Acta Cryst. A71 (2015) 3-8. https://doi.org/10.1107/S2053273314026370

[32] L. J. Farrugia, ORTEP-3 for Windows, an update, J. Appl. Crystallogr. 45 (2012) 849854. 
https://doi.org/10.1107/S0021889812029111

[33] F. Neri, M. Mari, S. Brigati, Control of PenicilliumExpansum by Plant Volatile

Compounds. Plant Pathol. 55 (2006) 100-105. https://doi.org/10.1111/j.1365$\underline{3059.2005 .01312 . x}$

[34] L. P. Garrod, F. O'Grady, Antibiotic and Chemotherapy, 3rd ed.;E. \& S. Livingstone: Edinburgh, 1972.

[35] G. K. Sandhu, R. Gupta, S. S. Sandhu, R. V. Parish, K. Brown, Diorganotin (IV) derivatives of N-phthaloyl amino acids, J. Organomet. Chem. 279(3) (1985) 373-384.

https://doi.org/10.1016/0022-328X(85)87035-2

[36] A. Yahyi, A. Et-Touhami, R. Yahyaoui, R. Touzani, Synthesis, characterization by means of IR, 1H, 13C-NMR and biological investigations on new diorganotin carboxylic acid derivatives, Lett. Drug Des. Discov. 7(7) (2010) 534-540.

https://doi.org/10.2174/157018010791526241

[37] X. Xiao, D. Du, M. Tian, X. Han, J. Liang, D. Zhu, L. Xu, Organotin (IV) carboxylates based on benzenedicarboxylic acid derivatives: Syntheses, crystal structures and characterizations, J. Organomet. Chem. 715 (2012) 54-63.

https://doi.org/10.1016/j.jorganchem.2012.05.038

[38] X. Xiao, Y. Li, Y. Dong, W. Li, K. Xu , N. Shi, P. Liu, "S" shaped organotin (IV) carboxylates based on amide carboxylic acids: syntheses, crystal structures and antitumor activities, J. Mol. Struc. 1130 (2017) 901-908. https://doi.org/10.1016/j.molstruc.2016.10.083

[39] V. Chandrasekhar, C. Mohapatra, R. K. Metre, Reactions of (E)-5-(Pyridin-4ylmethyleneamino) isophthalic Acid (LH2) with Triorganotin Oxides and- Chloride.Formation of One-Dimensional-and Two-Dimensional-Coordination Polymers, Cryst. Growth Des. 13(10) (2013) 4607-4614.

https://doi.org/10.1021/cg401201w

[40] M. K. Rauf, M. A. Saeed, M. Bolte, A. Badshah, B. Mirza,. Synthesis, characterization and biological activities of some new organotin (IV) derivatives: Crystal structure of [(Sn $\left.\left.\mathrm{Ph}_{3}\right)\left(\mathrm{OOCC}_{6} \mathrm{H}_{4} \mathrm{OH}\right)\right]$ and $\left[\left(\mathrm{SnMe}_{3}\right)_{2}(\mathrm{OOC})_{2} \mathrm{C}_{6} \mathrm{Cl}_{4}(\mathrm{DMSO})_{2}\right]$, J. Organomet. Chem. 693(18) (2008) 3043-3048. 
https://doi.org/10.1016/j.jorganchem.2008.06.027

[41] J. S. White, J; M. Tobin, Role of Speciation in Organotin Toxicity to the Yeast Candida maltose, Environ. Sci. Technol. 38 (2004) 3877-3884.

https://doi.org/10.1021/es030099k

[42] J. S. White, J. M. Tobin, Inorganic tin and organotin interactions with Candida maltose, J. Appl. Microbiol. Biotechnol. 63 (2004) 445-451.

https://doi.org/10.1007/s00253-003-1392-6 


\section{$\underline{\text { Figures captions }}$}

Fig. 1. Structure of bipyrazolic compounds functionalized with carboxylic groups

Scheme 1. Synthesis pathway of tin complexes C1-C7

Fig. 2. The secondary product due to the $1+1$ condensation

Fig. 3. FTIR spectra of $\mathbf{L 3}$ and $\mathbf{L} 7$ ligands and their corresponding complexes $\mathbf{C 3}$ and $\mathbf{C 7}$.

Fig. 4. UV-Visible spectra of $\mathbf{C 3}(\mathrm{A})$ and $\mathbf{C 7}(\mathrm{B})$.

Fig. 5. Molecular representation of $\mathbf{C 3}$

Fig. 6. Representation of the crystal structure of $\mathbf{C 3}$ projected in the $\left(\begin{array}{lll}1 & 0 & 1\end{array}\right)$ plane and emphasizing the hydrogen bonding (orange dashed lines).

Fig. 7. Molecular representation of $\mathbf{C 7}$

Fig. 8. Crystal structure of $\mathbf{C} 7$ projected on the (llll 101 ) plane. Weak interactions and hydrogen bonds are drawn as orange dashed lines.

Fig. 9. Percentage inhibition (\%) of FOA growth for the C1-C7 complexes and their L1-L7 ligands. 
Highlights

* New ditriphenyltin (IV) dicarboxylate complexes were synthesized.

* Spectroscopic measurement, NMR, IR, and UV of these complexes were studied.

*. Single crystal X-ray structure has been determined for two complexes.

* The antifungal activity against Fusarium oxysporum f. sp.albedinis was examined. 
Figure(s)

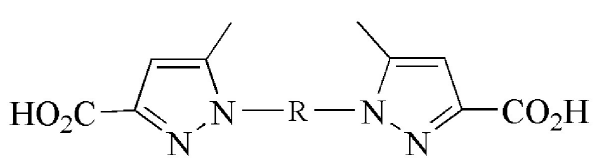

Fig. 1. 

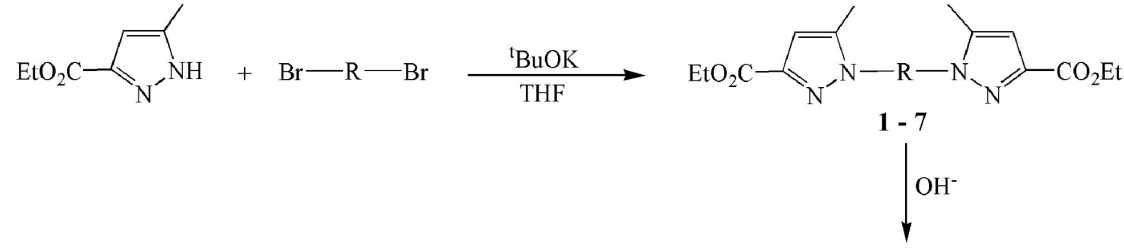

$\left(\mathrm{Ph}_{3}\right) \mathrm{Sn}-\mathrm{O}_{2} \mathrm{C}-\mathrm{N}_{\mathrm{N}}-\mathrm{N}-\mathrm{R}-\mathrm{N}$

C1 - C7

L1 - L7

$\begin{array}{ll}\text { 1; L1; C1: } & \mathrm{R}=-\left(\mathrm{CH}_{2}\right)^{-} \\ \text {2; L2; C2: } & \mathrm{R}=-\left(\mathrm{CH}_{2}\right)_{2^{-}} \\ \text {3; L3; C3: } & \mathrm{R}=-\left(\mathrm{CH}_{2}\right)_{3^{-}} \\ \text {4; L4; C4: } & \mathrm{R}=-\left(\mathrm{CH}_{2}\right)_{4^{-}} \\ \text {5; L5; C5: } & \mathrm{R}=-\left(\mathrm{CH}_{2}\right)_{5^{-}} \\ \text {6; L6; C6: } & \mathrm{R}=-\left(\mathrm{CH}_{2}\right)_{6^{-}} \\ \text {7; L7; C7: } & \mathrm{R}=-\left(\mathrm{CH}_{2}\right)_{2^{-}} \mathrm{O}-\left(\mathrm{CH}_{2}\right)_{2^{-}}\end{array}$

Scheme 1. 


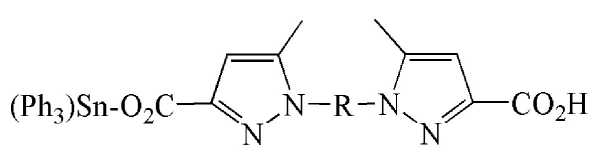

Fig. 2. 

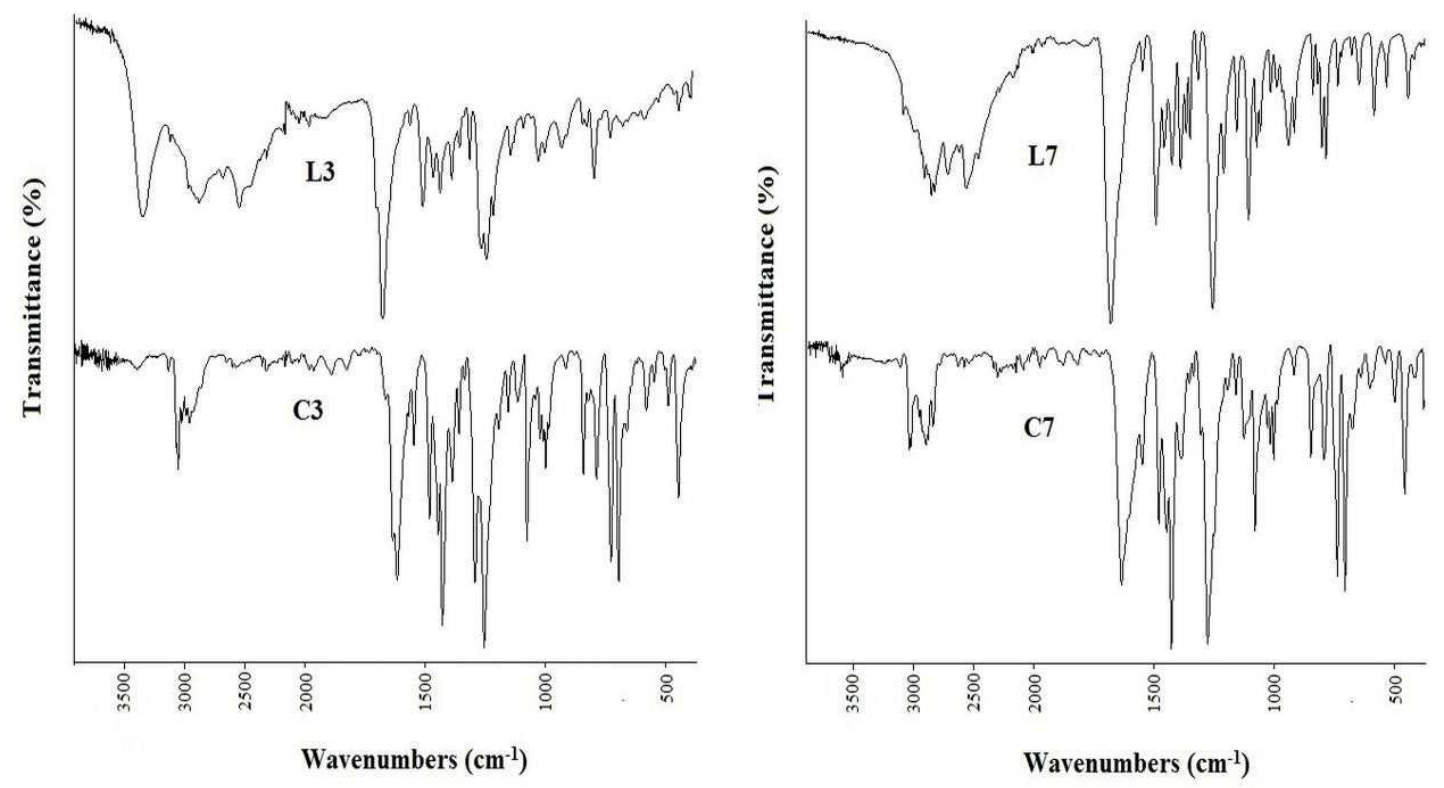

Fig. 3. 

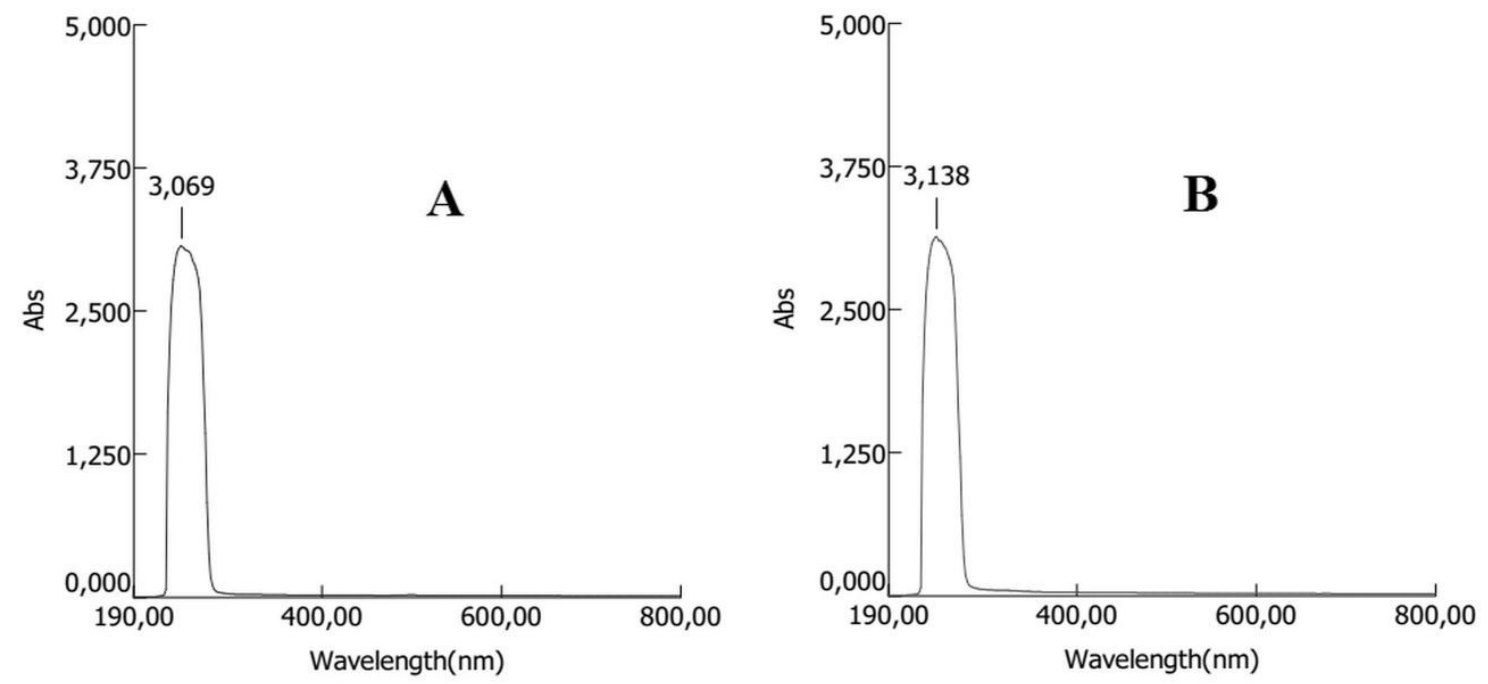

Fig. 4. 


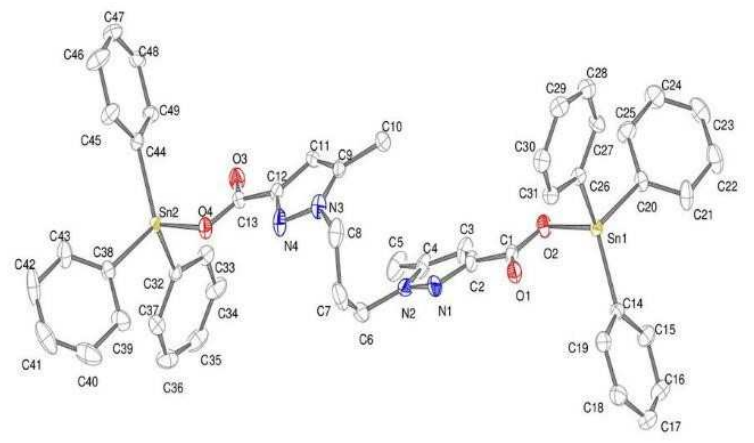

Fig. 5. 


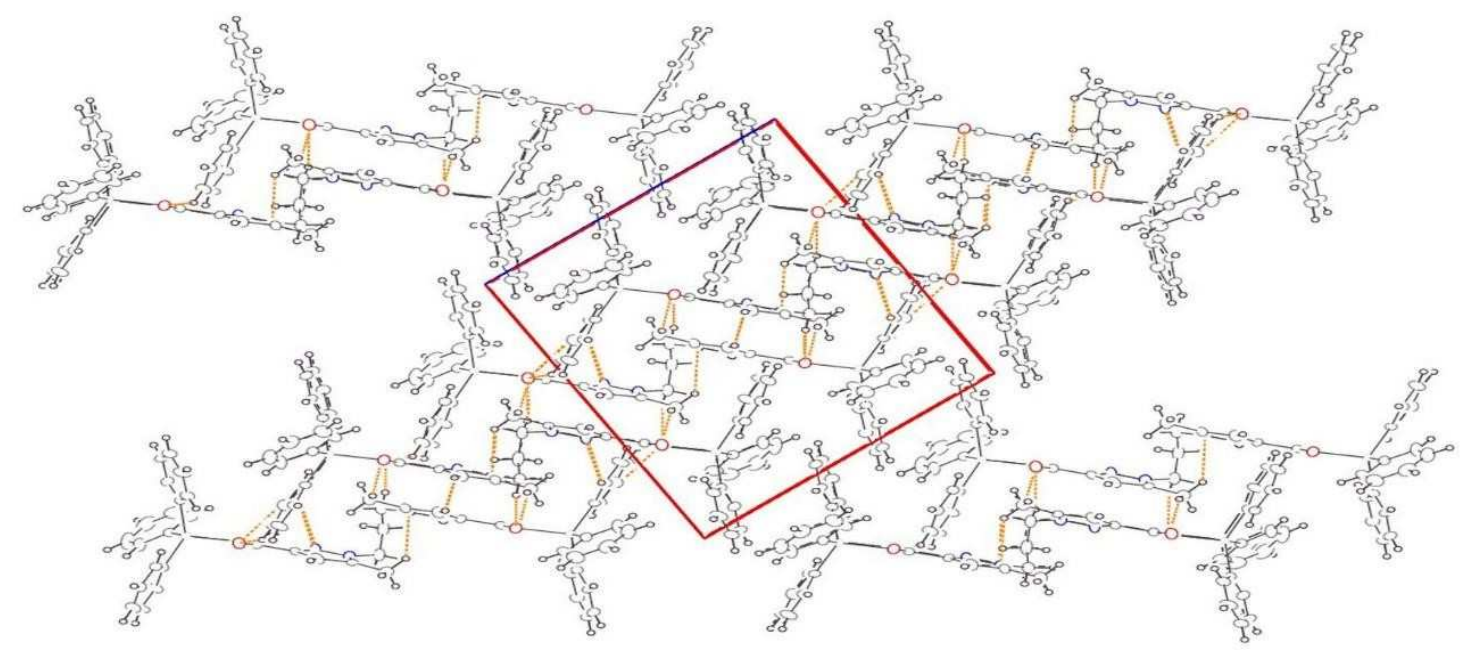

Fig. 6. 


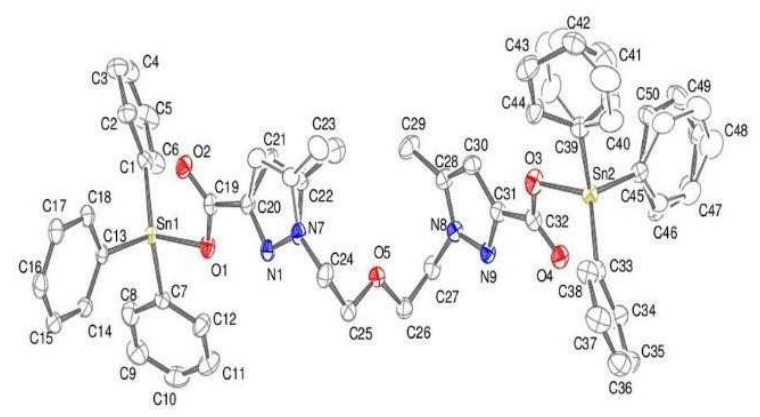

Fig. 7. 


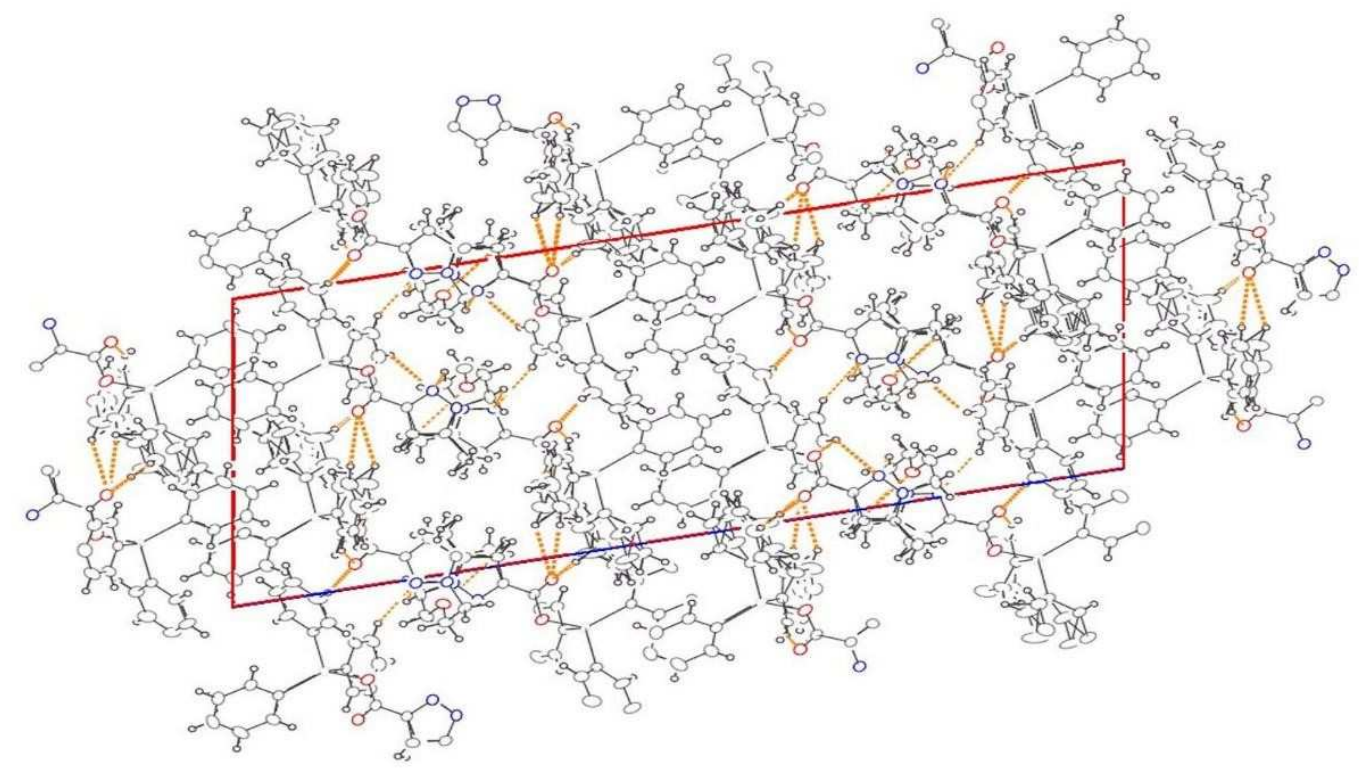

Fig. 8. 


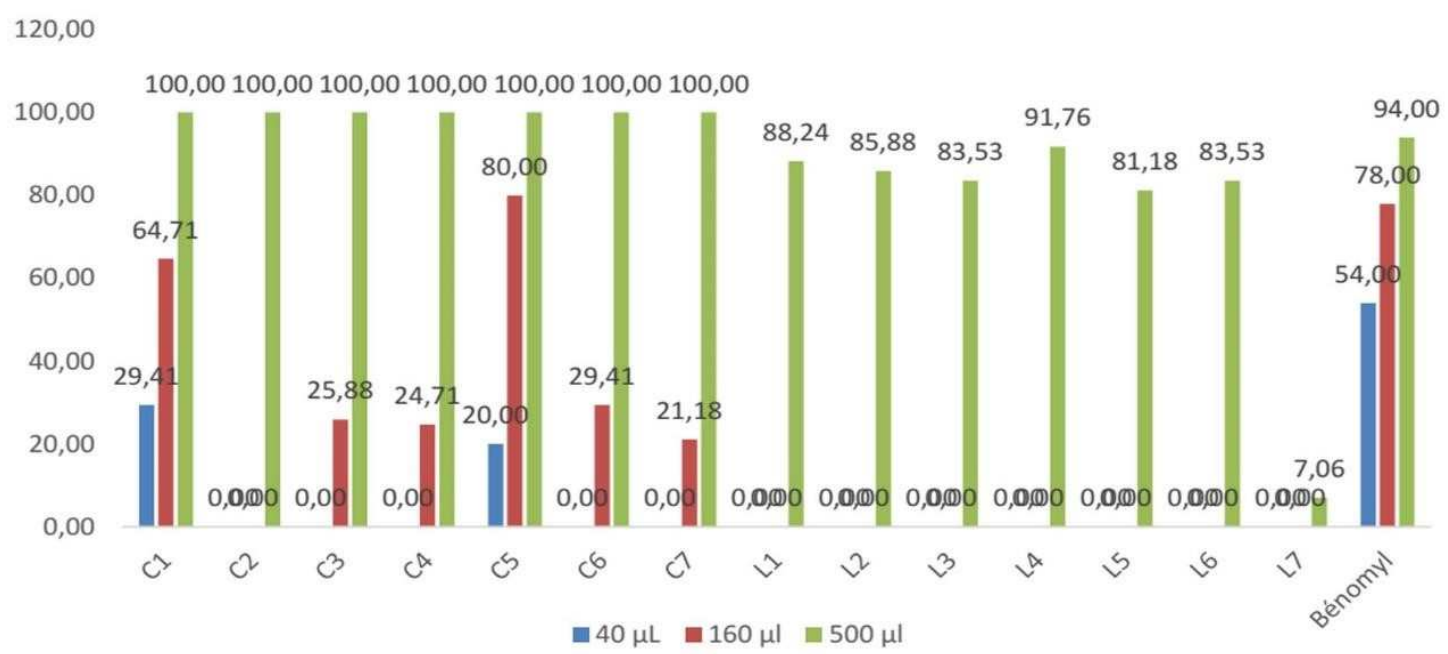

Fig . 9. 